African Journal of Pharmacy and Pharmacology Vol. 6(47), pp. 3246-3251, 22 December, 2012

Available online at http://www.academicjournals.org/AJPP

DOI: $10.5897 / A J P P 12.444$

ISSN 1996-0816 @2012 Academic Journals

\title{
Studies on the effect of gold nanoparticles on oxidative stress and antioxidants defense indices in various rat tissues
}

\author{
Nikhat Jamal Siddiqi ${ }^{1 *}$, Mohammad Anwar Kasim Abdelhalim² ${ }^{2}$ Yusra Ahmed AlYafee ${ }^{1}$ and \\ Abdullah Salih Alhomida ${ }^{1}$ \\ ${ }^{1}$ Department of Biochemistry, College of Science, King Saud University, P.O. Box 22452 and 2455, \\ Riyadh-11495, Saudi Arabia. \\ ${ }^{2}$ Physics and Astromy, King Saud Univeristy, PO Box 2455, Riyadh-11451, Saudi Arabia.
}

Accepted 26 November, 2012

\begin{abstract}
Gold nanoparticles (AuNPs) have a wide range of applications in various fields. It is therefore essential to study their interaction with the biological system. In the present study, the effect of AuNP was studied on oxidative stress and antioxidants in various tissues of rats. In this study, liver was the organ most sensitive to the effects of AuNP. Liver of AuNP treated rats showed a significant increase in lipid peroxidation, reduced glutathione and ascorbic acid when compared with the control group. This was followed by kidneys which showed significant increase in reduced glutathione and ascorbic acid when compared to the control group. Spleen showed a significant increase in the ascorbic acid concentration when compared with that of control rats. Heart tissue was most resistant to the effects of AuNP and showed no significant change in any of the oxidative stress and antioxidant indices studied. These results suggest that at low concentration, the properties of AuNP could be exploited for use in nanoimmunology, nanomedicine, nanobiotechnology and various other fields.
\end{abstract}

Key words: Gold nanoparticles (AuNPs), oxidative stress, antioxidants, rat tissues, antioxidant enzymes.

\section{INTRODUCTION}

Nanoparticles have a wide range of applications due to their unique properties. Gold nanoparticles (AuNPs) can easily enter cells (Connor et al., 2005) and the demonstration that amine and thiol groups bind strongly to AuNP has enabled their surface modification with amino acids and proteins for biomedical applications (Dani et al., 2008; Shukla et al., 2005; Xu and Han, 2004). AuNP are used in biosensors where they markedly enhance

*Corresponding author. E-mail: nikhat@ksu.edu.sa. Tel: +96614769137. Fax: +9661-4769137.

Abbreviation: AuNP, Gold nanoparticles. sensitivity and specificity of detection, because of their unique physical, chemical, mechanical, magnetic and optical properties (Zhang et al., 2009). Gold nanoparticles are also potential candidates for use in food industry due to their antimicrobial properties. Beside their useful effects, the interaction of nanomaterials with the biological system may also cause undesirable effects. There are conflicting reports about oxidative stress and cytotoxicity of gold nanoparticles (Jia et al., 2009; Renault et al., 2008; Tedesco et al., 2008; Tedesco et al., 2010a,b; Cho et al., 2009; Murphy et al., 2008). Crucial variables seem to be physical dimensions, surface chemistry, shape, method of synthesis, concentration and time of exposure (Tedesco et al., 2010a,b). In the present study, rats were injected with gold nanoparticles $(20 \mathrm{~nm})$ 
for three days and their effects on oxidative stress and antioxidant defense indices were investigated in different tissues.

\section{MATERIALS AND METHODS}

\section{Animals}

Male Wister rats weighing 150 to $200 \mathrm{~g}$ were obtained from the animal house of Pharmacy College of King Saud University, Riyadh. After one week of acclimatization period, the rats were injected with $20 \mu \mathrm{g} / \mathrm{kg}$ body weight of $20 \mathrm{~nm}$ AuNP for three days through the intraperitoneal route (ip). This route of administration of AuNPs was chosen, because it has been reported to be more toxic than other routes even in small doses (Sabella et al., 2011).

Rats were killed by carbon dioxide asphyxiation $24 \mathrm{~h}$ after the last dose of AuNP injection. Ethical animal care guidelines were followed.

\section{Chemicals}

All the chemicals used were purchased from Sigma Chemical Company, St Louis, MO, USA. Double distilled water was used throughout the study.

\section{AuNPs}

AuNPs of $20 \mathrm{~nm}$ purchased (Product MKN-Au-020) in aqueous solution of $0.01 \%$ concentration of gold; Canada were used in this study.

\section{Preparation of sample}

The rats were killed by carbon dioxide asphyxiation $24 \mathrm{~h}$ after the last dose of AuNP injection. The tissues were dissected out, washed in ice cold saline and homogenized in saline (10\% weight/volume) at $4^{\circ} \mathrm{C}$. The homogenates were centrifuged at 3000 rpm for $10 \mathrm{~min}$ in a cooling centrifuge. This supernatant was divided into two parts, namely, $A$ and $B$. Fraction $A$ was used for immediate determination of lipid peroxidation, reduced glutathione and ascorbic acid. Fraction A was further centrifuged at $6000 \mathrm{rpm}$ for 10 min in a cooling centrifuge. The supernatant constituted fraction $B$. This was used for estimation of catalase activity.

\section{Lipid peroxidation}

Lipid peroxidation was determined by the method of Utley et al. (1967). One milliliter of homogenate was incubated in metabolic shaker at $37^{\circ} \mathrm{C}$ for 1 h. $1.5 \mathrm{ml}$ of $20 \%$ trichloroacetic acid (TCA) was added to it and centrifuged at $600 \mathrm{~g}$ for $10 \mathrm{~min}$. To $1 \mathrm{ml}$ of supernatant was added fresh $1 \mathrm{ml}$ of thiobarbituric-acid (TBA, $0.67 \%$ ). The reaction was kept in water bath for $10 \mathrm{~min}$. On cooling, absorbance was read at 535 using a reagent blank.

Values were expressed as nmoles of thiobarbituric acid reactive substances (TBARS) formed hour ${ }^{-1} \mathrm{mg} \mathrm{protein}^{-1}$.

\section{Reduced glutathione}

Reduced glutathione was estimated by the method of Beutler et al. (1963). $0.4 \mathrm{ml}$ of homogenate was mixed with $3.6 \mathrm{ml}$ of double distilled water and treated with $0.6 \mathrm{ml}$ of precipitation reagent (containing $1.67 \mathrm{~g}$ of glacial metaphosphoric acid, $0.2 \mathrm{~g}$ of ethylenediaminetetraacetic acid (EDTA) and $30.0 \mathrm{~g}$ of $\mathrm{NaCl}$ and made up to $100 \mathrm{ml}$ with double distilled water). The reaction mixture was centrifuged at $600 \mathrm{~g}$ for $10 \mathrm{~min}$. To $0.3 \mathrm{ml}$ of supernatant was added $2.00 \mathrm{ml}$ of $\mathrm{Na}_{2} \mathrm{HPO}_{4}(0.3 \mathrm{M}), 0.25 \mathrm{ml}$ of $5,5^{\prime}$ dithio-bis-2nitrobenzoic acid $(0.4 \%$ in $1 \%$ sodium citrate) and volume made up to $3.0 \mathrm{ml}$ with double distilled water. Absorbance was read at 412 $\mathrm{nm}$ against blank. The amount of ascorbic acid was calculated from the standard graph. Values were expressed as $\mu \mathrm{g}$ of reduced glutathione $\mu \mathrm{g}$ protein $^{-1}$.

\section{Ascorbic acid}

Ascorbic acid was determined by the method of Jagota and Dani (1982). $0.2 \mathrm{ml}$ of homogenate was treated with $0.8 \mathrm{ml}$ of $10 \%$ TCA. After vigorous shaking, tubes were kept in ice cold bath for 5 min and centrifuged at $1200 \mathrm{~g}$ for $5 \mathrm{~min}$. 0.2 to $0.5 \mathrm{ml}$ of the supernatant were diluted to $2 \mathrm{ml}$ with distilled water and $0.2 \mathrm{ml}$ of Folin reagent $(0.2 \mathrm{M})$ was added in it. After $10 \mathrm{~min}$, the absorbance was read at $760 \mathrm{~nm}$ against a reagent blank. The amount of ascorbic acid was calculated from the standard graph. Values were expressed as $\mu \mathrm{g}$ of ascorbic acid $\mu \mathrm{g}$ protein $^{-1}$.

\section{Catalase}

Catalase activity was estimated in the whole homogenate by the method of Aebie (1984). The reaction mixture in a total volume of 3 $\mathrm{ml}$ contained $1.5 \mathrm{ml} 0.2 \mathrm{M}$ sodium phosphate buffer $\mathrm{pH} 7.2,1.2 \mathrm{ml}$ of $\mathrm{H}_{2} \mathrm{O}_{2}$ and suitably diluted enzyme. The reaction was started by adding $\mathrm{H}_{2} \mathrm{O}_{2}$ and reading the change in absorbance at $240 \mathrm{~nm}$ for 2 min. Values were expressed as millimoles of $\mathrm{H}_{2} \mathrm{O}_{2}$ consumed min $^{-1}$ $\mathrm{mg}_{\text {protein }}{ }^{-1}$.

\section{Protein}

The protein content in the sample was measured by the modified method of Markwell et al. (1978) using bovine serum albumin as the standard. The amount of protein was calculated from the standard graph.

\section{Statistical analysis}

Each sample was run in duplicate. Values were expressed as mean \pm standard deviation (SD) tissue, for $n=5$ to 6 rats. Values between groups were compared using Dunnet's comparison tests. Values were considered significant if $P<0.05$. Statistical analysis was performed by means of In-Stat package for personal computers version 5 (GraphPad_Software, Inc., San Diego, USA).

\section{RESULTS AND DISCUSSION}

Nanotechnology involves the study of the control of matter on atomic and molecular scales. Nanotechnology is being applied in diverse fields, including extensions of conventional device physics, new approaches based upon molecular self-assembly, the development of novel materials with dimensions on the nanoscale, and even the direct control of matter on the atomic scale. The 


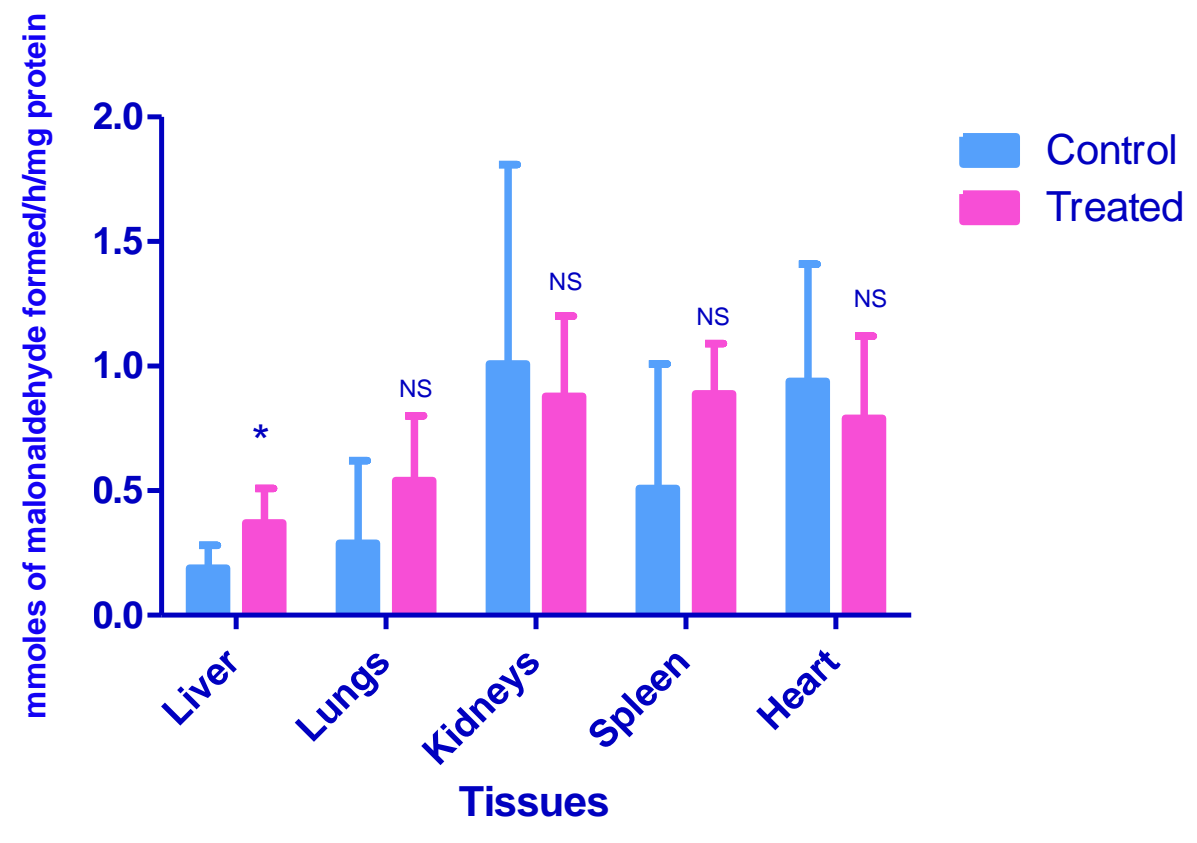

Figure 1. The effect of injected AuNPs on lipid peroxidation in different tissues of rats. Values are expressed as $\pm S D$ nmoles of thiobarbituric-acid reactive substances formed/h/mg protein. ${ }^{*} \mathrm{P}<0.05$; NS: Non significant.

application of nanotechnology in biology (nanobiotechnology) encompasses development of nanomaterials for delivering and monitoring biologically active molecules, disease staging, therapeutical planning, surgical guidance, neuro-electronic interfaces, and electronic biosensors (Huang et al., 2010). Nanoparticles possess better tissue penetration and higher biological potency than coarse $(2.5$ to $10 \mu \mathrm{m})$ and fine $(<2.5 \mu \mathrm{m})$ particles due to their small sizes and large reactive surfaces (Huang et al., 2010). However, it is also essential to understand the adverse effects of nanoparticles on the biological system. Oxidative stress is a causative factor for many diseases and underlying pathologies. In this study, AuNP were found to induce significant oxidative stress in the liver of rats. Oxidative stress plays important roles in cellular signaling, inflammatory, and genotoxic and proliferative responses (Schins, 2003; Knaapen et al., 2004; van Maanen et al., 1999; Driscoll et al., 1997; Zhong et al., 1997; Leanderson and Tagesson, 1992; Borm et al., 2004).

Figure 1 shows the effect of injected AuNP on lipid peroxidation in different tissues in rats. The size and dose of the nanoparticles used caused a significant increase in lipid peroxidation of $95 \%(P<0.05)$ in liver when compared with the liver of the control group of rats. In the other organs studied, namely, lungs, kidneys, spleen and heart, there was no significant change in lipid peroxidation when compared with the control group of rats $(P>0.05)$. Nanoparticles have the potential to interact with the biological system and cause undesirable effects. One of these damaging effects could be the disturbance in the natural balance between oxidative stress and antioxidant defense indices which in turn can lead to various pathologies. Oxidative stress has been identified as a likely mechanism of nanoparticle toxicity (Li et al., 2008). Since liver is an important organ for storage of iron, it may be susceptible to lipid peroxidation than other tissues. AuNPs are taken up by the Kupffer cells of the liver and their bioaccumulation is regulated by the reticuloendothelial system.

To cope with elevated oxidative stress, cells mount protective or injurious responses. For instance, cells activate enzymatic and non-enzymatic antioxidant defense mechanisms like glutathione peroxidases, catalases, superoxide dismutases, etc (Huang et al., 2010). Figure 2 shows the effect of injected AuNPs on reduced glutathione concentration in various tissues in rats. The AuNPs caused a significant increase in reduced glutathione on liver, lungs and kidneys. There was however no significant change in spleen and heart $(P>$ $0.05)$. The increase in reduced glutathione was the highest in kidneys $(1130 \%$; $P<0.001)$, followed by lungs $(118 \% ; P<0.05)$ and liver which was $65 \%(P<0.05)$ when compared with the control group. The changes in reduced glutathione levels in the other tissues like spleen and heart was not significant $(P>0.05)$. Glutathione is one of the primary cellular antioxidant defenses against oxidative stress. Glutathione is a tripeptide 


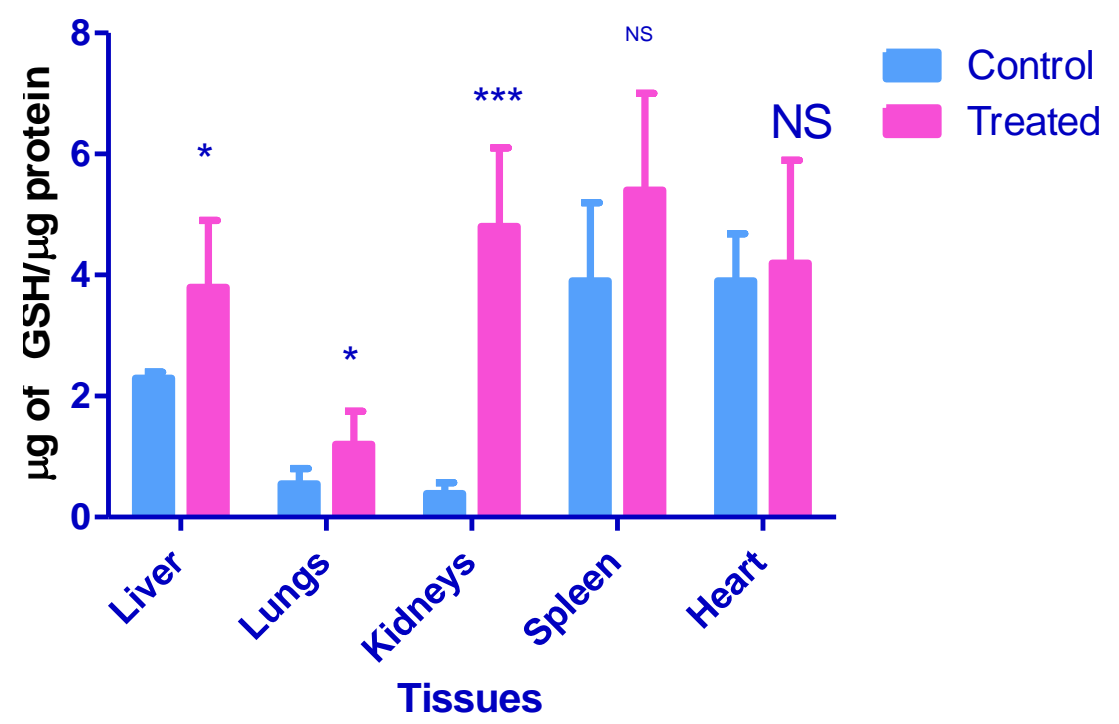

Figure 2. The effect of injected AuNPs on reduced glutathione concentration in different tissues in rats. Values were expressed as $\pm S D \mu g$ of reduced glutathione $\mu \mathrm{g}$ protein $^{-1}$. ${ }^{\star} \mathrm{P}<0.05$; $^{\star \star \star} \mathrm{P}<0.001$; NS: Non significant.

(v-glutamylcysteinylglycine present intracellularly in millimolar concentrations. The cysteine amino acid in glutathione can function as a thiol reducing agent, thus buffering cellular oxidants. Glutathione homeostasis is predominantly regulated by a complex cycle of synthesis and catabolism that occurs in the liver, lung, and kidney. Under physiological conditions, glutathione reductase rapidly reduces any oxidized glutathione (GSSG) to its thiol form (GSH), so that under normal conditions more than $98 \%$ of intracellular glutathione is GSH (Deleve and Kaplowitz, 1991). In the present study, nanoparticle treatment caused a significant increase in reduced glutathione which may be due to increase in lipid peroxidation in the liver and a preventive measure in lungs and kidneys. Although there are multiple potential detoxification mechanisms that affect the efficacy of chemotherapeutic drugs and confer drug resistance to targeted cells (Du et al., 2009), GSH has a prominent role in resistance to chemotherapy (Chen et al., 1998). GSH and its associated enzymes play a critical role in the cell susceptibility to the cytotoxic effect of alkylating agents, doxorubicin, cisplatin and nitrosoureas (Tew, 1994). It has been shown that for these drugs, increased cellular GSH levels can confer cells resistance and decreased cellular GSH levels can sensitize cells to the killing effects (Chiba et al., 1996; Yang et al., 2000).

Figure 3 shows the effect of injected AuNP on ascorbic acid content in various rat tissues. Injection of AuNP caused an increase of $142 \%(P<0.05)$ in kidneys, $111 \%$ $(P<0.001)$ in liver and 91\% $(P<0.001)$ in spleen when compared with the control rats. There was however no significant change in the ascorbic acid content in heart and lungs $(P>0.05)$. Ascorbic acid is a well known antioxidant. The antioxidant function of vitamin $\mathrm{C}$ is to neutralize the free radicals. In liver, the increase in vitamin C may be a response to lipid peroxidation. Alternatively, the higher increase in vitamin $C$ levels in other tissues like lungs, kidneys and spleen might have prevented significant increase in lipid peroxidation in these tissues.

Figure 4 shows the effect of injected AuNPs on catalase activity in various rat tissues. The results show that the AuNPs caused no significant change $(P>0.05)$ in catalase activity in any of the tissues studied. Catalase is the enzyme responsible for dissipation of hydrogen peroxide formed during oxidative stress. Catalase has been reported to be expressed in relatively low constitutive level in cardiomyocytes (Huang et al., 2010). In the present study, AuNPs injection in rats caused no significant change in the catalase activity in all the tissues studied. Reactive oxygen species (ROS) including $\mathrm{H}_{2} \mathrm{O}_{2}$ have dual role in the living system. They can oxidize cell components and lead to inactivation of certain enzymes as well as ROS are known to be involved in oxygen sensing and signal transduction as second messengers (Bagnyukova et al., 2005). Since catalase was not significantly altered by nanoparticle treatment, it might be suggested that $\mathrm{H}_{2} \mathrm{O}_{2}$ might not have been generated in significant amount by the AuNPs to elicit an alteration in the catalase activity.

Therefore, the concentration and/or the type of AuNP in this study may not be toxic to all the organs in rats. These results are in agreement with the study of Shukla et al. (2005) indicating their potential for application in 


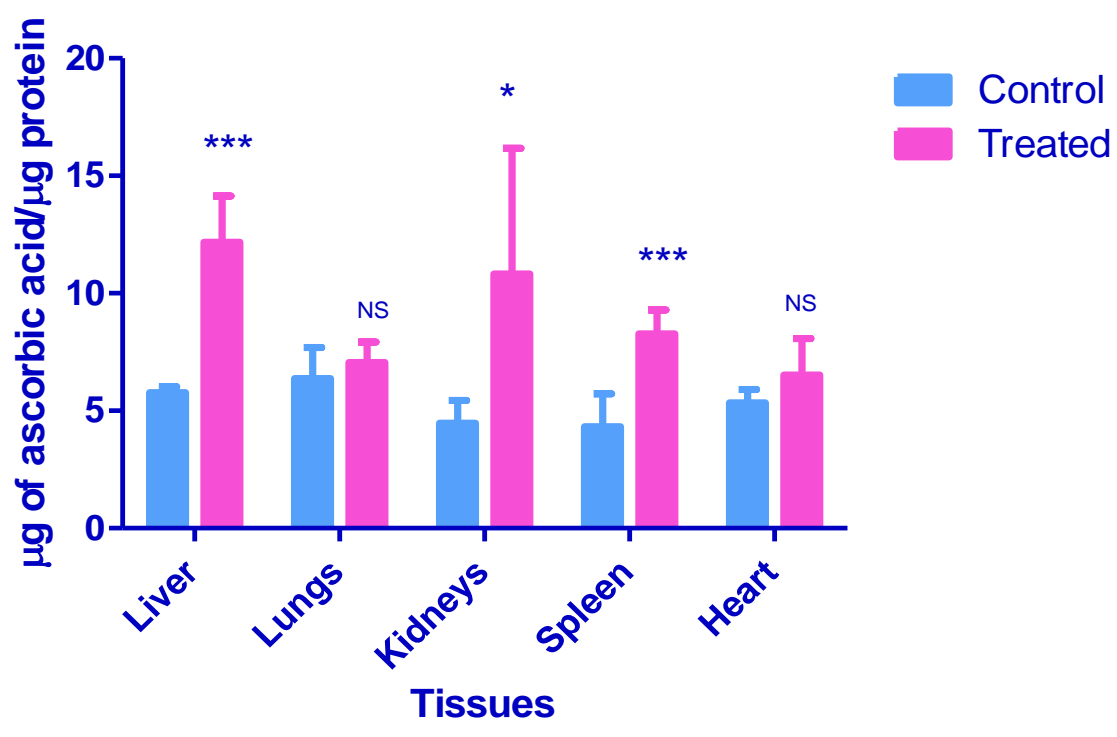

Figure 3. The effect of injected AuNPs on ascorbic acid concentration in different tissues in rats. Values were expressed as $\pm S D \mu g$ of ascorbic acid $\mu g$ protein $^{-1}$. ${ }^{* * *} \mathrm{P}<0.001$; NS: Non significant.

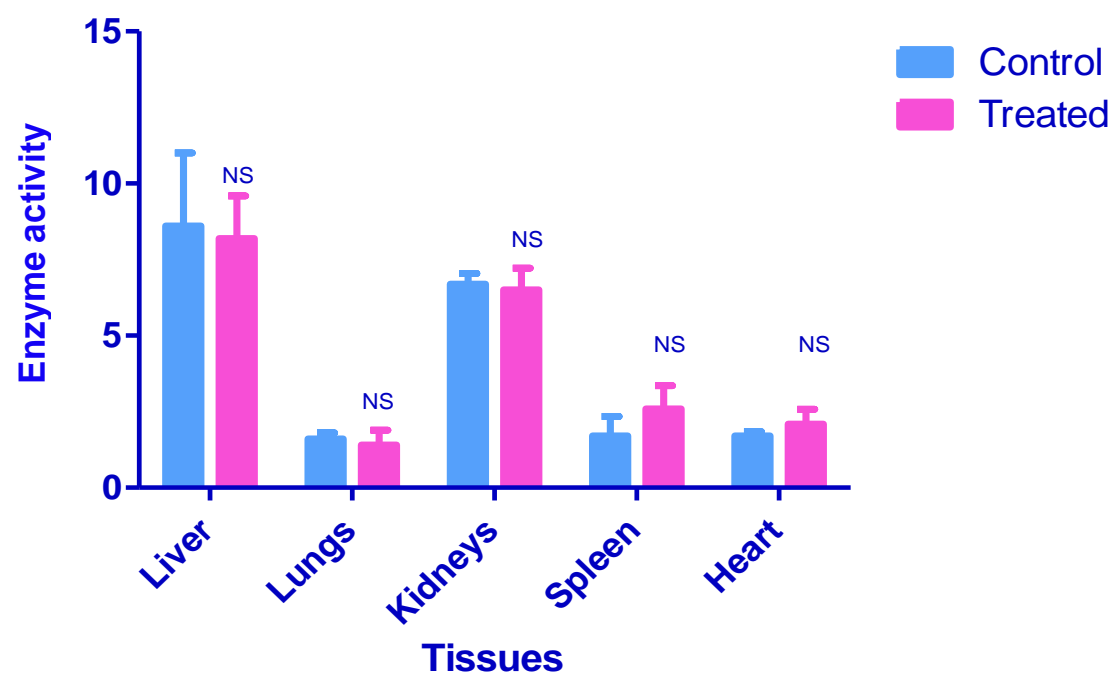

Figure 4. The effect of injected AuNPs on catalase activity in different tissues in rats. Values were expressed as $\pm S D$ millimoles of $\mathrm{H}_{2} \mathrm{O}_{2}$ consumed $\mathrm{min}^{-1} \mathrm{mg}$ protein $^{-1}$. NS: Non significant.

nanoimmunology, nanomedicine, and nanobiotechnology.

\section{Conclusion}

The low doses of AuNPs used in this study caused a significant change in the oxidative stress and antioxidant defense indices only in the liver. Therefore, they offer potential to be exploited for various in vivo uses.

\section{ACKNOWLEDGEMENTS}

The authors are grateful to National Plan of Science and Technology (NPST). This research was financially supported by the National Science and Technology Innovation Plan (NSTIP), Research No. 08-ADV206-02 
and Research No. 09-NAN670-02, College of Science, King Saud University, Saudi Arabia.

\section{REFERENCES}

Aebie H (1984). Catalase in vitro. Academic Press Inc., London. Meth. Enzymol. 105:121-126.

Bagnyukova TV, Vasylkiva OY, Storeyb KB, Lushchaka VI (2005). Catalase inhibition by amino triazole induces oxidative stress in goldfish brain. Brain Res. 1052:180-186.

Beutler E, Duron O, Kelly BM (1963). Improved method for the determination of blood glutathione. J. Lab. Clin. Med. 61:882-888.

Borm PJ, Schins RP, Albrecht C (2004). Inhaled particles and lung cancer, Part B: Paradigms and risk assessment. Int. J. Cancer 110:3-14.

Chen X, Carystinos GD, Batist G (1998). Potential for selective modulation of glutathione in cancer chemotherapy. Chem. Biol. Interact. 111-112:263-275.

Chiba T, Takahashi S, Sato N, Ishii S, Kikuchi K (1996). Fas-mediated apoptosis is modulated by intracellular glutathione in human $\mathrm{T}$ cell. Eur. J. Immunol. 26(5):1164-1169.

Cho WS, Cho M, Jeong J, Choi M, Cho HY, Han BS, Kim SH, Kim HO, Lim YT, Chung BH (2009). Acute toxicity and pharmacokinetics of $13 \mathrm{~nm}$-sized PEG-coated gold nanoparticles. Toxicol. Appl. Pharmacol. 236(1):16-24.

Connor EE, Mwamuka J, Gole A, Murphy CJ, Wyatt MD (2005). Gold nanoparticles are taken up by human cells but do not cause acute cytotoxicity. Small 1:325-327.

Dani RK, Kang M, Kalita M, Smith PE, Bossmann SH, Chikan V (2008). MspA porin-gold nanoparticle assemblies: enhanced binding through a controlled cysteine mutation. Nano Lett. 8:1229-1236.

Deleve LD, Kaplowitz N (1991). Glutathione metabolism and its role in hepatotoxicity. Pharmacol. Ther. 52:287-305.

Driscoll KE, Deyo LC, Carter JM, Howard BW, Hassenbein DG, Bertram TA (1997). Effects of particle exposure and particle-elicited inflammatory cells on mutation in rat alveolar epithelial cells. Carcinog. 18(2):423-430.

Du ZX, Zhang HY, Meng X, Guan Y, Wang HQ (2009). Role of oxidative stress and intracellular glutathione in the sensitivity to apoptosis induced by proteosome inhibitor in thyroid cancer cells. BMC Cancer 9:56. doi:10.1186/1471-2407-9-56.

Huang YW, Wu C, Aronstam RS (2010). Toxicity of Transition Metal Oxide Nanoparticles: Recent Insights from in vitro Studies. Mater. 3:4842-4859.

Jagota SK, Dani HM (1982). A new colorimetric technique for the estimation of vitamin $\mathrm{C}$ using folin-phenol reagent. Anal. Biochem. 127:178-182.

Jia HY, Liu Y, Zhang XJ, Han L, Du LB, Tian Q, Xu YC (2009). Potential oxidative stress of gold nanoparticles by induced-NO releasing in serum. J. Am. Chem. Soc. 131:40-41.

Knaapen AM, Borm PJ, Albrecht C, Schins RP (2004). Inhaled particles and lung cancer. Part A: Mechanisms. Int. J. Cancer 109:799-809.

Leanderson P, Tagesson C (1992). Hydrogen peroxide release and hydroxyl radical formation in mixtures containing mineral fibres and human neutrophils. Br. J. Ind. Med. 49:745-759.
Li N, Xia T, Nel AE (2008). The role of oxidative stress in ambient particulate matter-induced lung diseases and its implications in the toxicity of engineer enanoparticles. Free Radic. Biol. Med. 44:16891699.

Markwell MAK, Haas SM, Bieber LL, Tolbert NE (1978). A modification of the Lowry Procedure to simplify protein determination in membrane and lipoprotein samples. Anal. Biochem. 87:206-210.

Murphy CJ, Gole AM, Stone JW, Sisco PN, Alkilany AM, Goldsmith EC, Baxter SC (2008). Gold nanoparticles in biology: Beyond toxicity to cellular imaging. Acc. Chem. Res. 41:1721-1730.

Renault S, Baudrimont M, Mesmer-Dudons N, Gonzalez P, Mornet S, Brisson A (2008). Impacts of gold nanoparticle exposure on two freshwater species: A phytoplanktonic alga (Scenedesmus subspicatus) and a benthic bivalve (Corbicula fluminea). Gold Bull. 41:116-126.

Sabella S, Galeone A, Vecchio G, Cingolani R, Pompa PP (2011). AuNPs are toxic in vitro and in vivo: A review. J. Nanosci. Lett. 1:145165.

Schins RP (2002). Mechanisms of genotoxicity of particles and fibers. Inhal. Toxicol. 14:57-78.

Shukla R, Bansal V, Chaudhary M, Basu A, Bhonde RR, Sastry M (2005). Biocompatibility of gold nanoparticles and their endocytotic fate inside the cellular compartment: A microscopic overview. Langmuir 21(3):10644-10654.

Tedesco S, Doyle H, Blasco J, Redmond G, Sheehan D (2010a). Oxidative stress and toxicity of gold nanoparticles in Mytilus edulis. Aquat. Toxicol. 100:178-186.

Tedesco S, Doyle H, Blasco J, Redmond G, Sheehan D (2010b). Exposure of the blue mussel, Mytilus edulis, to gold nanoparticle and the pro-oxidant menadione. Comp. Biochem. Physiol. C: Pharmacol. Toxicol. 151:167-174.

Tedesco S, Doyle H, Redmond G, Sheehan D (2008). Gold nanoparticles and oxidative stress in Mytilus edulis. Mar. Environ. Res. 66:131-133.

Tew KD (1994). Glutathione-associated enzymes in anticancer drug resistance. Cancer Res. 54(16):4313-4320.

Utley HG, Berheim F, Hochstein P (1967). Effect of sulfhydryl reagent on peroxiation in microsomes. Arch. Biochem. Biophys. 118:29-32.

van Maanen JM, Borm PJ, Knaapen A, van Herwijnen M, Schilderman PA, Smith KR, Aust AE, Tomatis M, Fubini B (1999). In vitro effects of coal fly ashes: Hydroxyl radical generation, iron release, and DNA damage and toxicity in rat lung epithelial cells. Inhal. Toxicol. 11:1123-1141.

Xu S, Han X (2004). A novel method to construct a third-generation biosensor: self assembling gold nanoparticles on thiol-functionalized poly (styrene-co-acrylic acid) nanospheres. Biosens. Bioelectron. 19:1117-1120.

Yang CF, Shen HM, Ong CN (2000). Ebselen induces apoptosis in HepG(2) cell through rapid depletion of intracellular thiols. Arch. Biochem. Biophys. 374(2):142-152.

Zhang X, Guo Q, Cui D (2009). Recent advances in nanotechnology applied to biosensors. Sensors 9:1033-1053.

Zhong BZ, Whong WZ, Ong TM (1997). Detection of mineral-dustinduced DNA damage in two mammalian cell lines using the alkaline single cell gel/comet assay. Mutat. Res. 393(3):181-187. 